\title{
RESENHA
}

\section{PRINCÍPIOS E APLICACÕES DO CÁLCULO FINANCEIRO}

\section{CLOVIS DE FARO}

Rio de Janeiro, Livros Técnicos e Científicos, 1990.

\section{Por Francisco Aranha}

Professor do Departamento de Informática e Métodos Quantitativos da EAESP/FGV e consultor de empresas.

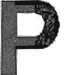

ara o brasileiro de nossos dias, o cálculo financeiro é quase uma segunda natureza. Seja com facilidade ou com hesitação, de maneira intuitiva ou racional, acertando ou errando em suas conclusões, ele faz suas contas tranqüilamente. Às vezes, sem ao menos se aperceber da complexidade do processo envolvido, ele maneja as taxas de juros como quem fala português.

Optar por um pagamento à vista, com desconto, ou em vários cheques, pelo valor integral. Adquirir ou alugar uma linha telefônica. Financiar um veículo ou participar de um grupo de consórcio. Avaliar a política salarial da empresa. Repactuar o aluguel do apartamento. Recalcular as prestações da casa própria. Todas estas são questões do cotidiano, sobre as quais todos têm opinião. Daí, o grande interesse despertado pela disciplina, mesmo entre os que não a estudam por dever de ofício, como os administradores, contadores e economistas.

Refletindo esse interesse, o mer- cado editorial tem presenciado nos últimos anos o lançamento de um grande número de obras que cuidam do assunto. Uma das mais recentes foi publicada pela editora Livros Técnicos e Científicos. Tratase de Principios e Aplicaçóes do Cálculo Financeiro, do Prof. Clovis de Faro.

O Prof. Faro graduou-se em Engenharia Civil na Universidade Federal Fluminense em 1964 e pósgraduou-se na Stanford University, respectivamente em Pesquisa Operacional e Engenharia Industrial. Leciona a disciplina Matemática Financeira desde 1967; portanto, há mais de duas décadas. É o autor dos bastante conhecidos compêndios Engenharia Econômica e Matemática Financeira. Este último, que em 1989 se encontrava na quarta tiragem da nona edição, serviu de base para o presente trabalho.

Segundo o autor, o principal motivo que o levou a escrever um novo livro foi o fato de que o Matemática Financeira, publicado pela primeira vez em 1969, não mais refletia de maneira fiel o seu pensamento sobre o assunto.

Para quem não conhece o trabalho anterior, Princípios e Aplicações do Cálculo Financeiro apresentar-seá como um texto avançado, com uma evidente preocupação em dar um tratamento teórico abrangente aos tópicos abordados. Apesar disso, o autor consegue uma exposição clara e simples, se bem que não necessariamente fácil. O desenvolvimento matemático do tema não é trivial e exige um leitor qualificado: utiliza uma notação rigorosa e re- sultados fortes, que não demonstra.

No primeiro capítulo, o autor apresenta o conceito de juros, o regime de capitalização contínuo e o descontínuo; mostra como este último se subdivide em simples ou composto, conforme os juros periodicamente formados rendam também juros ou não. No tratamento dado ao tema, apóia-se extensivamente nas ferramentas do cálculo diferencial e integral; em conseqüência, o texto fica totalmente fora do alcance de um aluno que não tenha tido um bom curso básico nessas áreas. O próprio autor reconhece que, na falta de um adequado embasamento em cálculo, o capítulo deve ser omitido. No entanto, em nossa opinião, não deixa de ser desajeitado um texto cujo trecho introdutório deve ser saltado.

Nos dois capítulos seguintes, o autor trata em detalhe dos regimes de juros simples e compostos. O destaque dado à diferença de comportamento desses regimes em relação à cindibilidade do prazo e à data focal proporciona uma forte compreensão dos aspectos que os distinguem. A clareza do texto resulta da apresentação de forma bem organizada e consistente das categorias e da notação: valor presente, valor futuro, valor atual, juro comercial, juro exato, rentabilidade etc. recebem tratamento preciso. A enfâse nos aspectos teóricos e matemáticos, contudo, faz com que as aplicaçôes práticas dos conceitos percam um pouco do seu relevo. Isto nos parece patente, por exemplo, no caso da discussão dos al- 
goritmos de Newton-Raphson e de Bouling, sem uma correspondente exploração da utilidade do cálculo da taxa interna de retorno.

No capítulo quarto, examinamse os diversos tipos de taxas e o efeito da inflação. Mais uma vez, chama a atenção sobre como a escolha muito feliz das categorias empregadas, que permite eliminar ambigüidades: nesse caso, as definições adotadas tornam específico o conceito de taxa nominal, por oposição à taxa efetiva, ficando os conceitos de taxa real e aparente ligados ao processo inflacionário.

O capítulo quinto aborda os empréstimos bancários, analisando os diversos tipos de operações de desconto. Essas operações são caracterizadas como de curto prazo. O impacto da tributação e da exigência de reciprocidade é avaliado. $\mathrm{Na}$ seqüência, o capítulo sexto enfoca os prazos médio e longo, tratando das leis de formação das séries de pagamentos. Os dois capítulos finais tratam da amortização de dívidas e dos empréstimos indexados.

Além dos aspectos acima mencionados, Princípios e Aplicações do Cálculo Financeiro oferece um interesse adicional para quem já conhecia o trabalho anterior: o de pos sibilitar que se vislumbre como o pensamento de um autor evolui ao longo de mais de vinte anos de experiência em sala de aula e de pesquisas sobre um tema. No livro novo, é possível identificar o material que já existia no livro velho, o que foi abandonado ou modificado e o que foi incluído. Pode-se perce- ber o processo de depuração, de simplificação, de busca do que é essencial à teoria. Pode-se notar, pela mudança no enfoque, como o autor conseguiu uma abordagem mais abrangente, uma notação e uma sistematização mais consistentes e mais elegantes. Pode-se, enfim, imaginar quanta reflexão está cristalizada neste trabalho e entender um pouco por que realizações de nível tão alto quanto esta não são tão freqüentes.

Agora, uma queixa. Embora o Prof. Faro tenha incluído nesta sua nova obra um muito bem-vindo indice remissivo, coisa que não acontecia em Matemática Financeira, resta uma lacuna das mais graves: falta uma bibliografia final. Não se pode dizer que, por terem as obras citadas aparecido em notas de rodapé, está o autor dispensado de fornecer uma bibliografia final. Esta tem a finalidade de dar uma visão geral do material consultado e fornecer informações sobre a literatura referente ao assunto tratado no livro. E, além do mais, é uma gentileza com o leitor poupar-lhe o trabalho de sair à caça, página por página, de uma referência que ele queira reexaminar.

O trabalho editorial da LTC foi também de excelente qualidade. $\mathrm{O}$ formato escolhido para o livro, um pouco maior do que o habitualmente encontrado nos livros de texto, é muito confortável. Pelo que pude notar, esse padrão foi utilizado pela editora em todas as suas publicações que tive oportunidade de examinar recentemente. A programação visual desenvolvida é pri- morosa, desde a capa, de muito bom gosto e equilíbrio, passando pelo tipo de letra empregado, pelo agradável espaçamento entre os parágrafos, pelo correto tratamento das fórmulas matemáticas, chegando até a diagramação, muito limpa. Não identifiquei erros de impressão que se destacassem, o que sugere uma revisão cuidadosa. Notei, no entanto, pequenos problemas à página 32.

Um último comentário. A nosso ver, Principios e Aplicaçöes do Cálculo Financeiro é um livro para quem já conhece bem o assunto. Pelo seu alto grau de abstração e generalidade, bem como pela sua abordagem fortemente matematizada, requer que o leitor já esteja bem familiarizado tanto com os fundamentos básicos da matemática financeira quanto com a sua aplicação às situações práticas.

Trata-se, portanto, de um material mais condizente com um curso avançado. Julgo que dificilmente seria adequado para um primeiro contato com a disciplina, ainda que para isso houvesse todo um ano letivo à disposição. Nesse particular, estou francamente em desacordo tanto com o autor, que se manifesta de maneira diversa no prefácio, quanto com a editora, pelo que esta expressa na última capa. No entanto, acho essa divergência compreensível: a exclusão da formação básica do universo de aplicações desta obra restringe o seu mercado. E, afinal, sob muitos aspectos, um livro é também um produto para ser vendido. De preferência, em grande quantidade. $\square$ 